\title{
The Effect of Export Promotion Programs on Egypt's Textiles, Clothing and Home Textiles Export Performance
}

\author{
Mona El Garf ${ }^{1}$, Sayed Moawad Ahmed ${ }^{2}$ \\ ${ }^{1}$ Professor of Economics, Faculty of Economics and Political Science, Cairo University; \\ ${ }^{2} \mathrm{PhD}$ Candidate, Faculty of Economics and Political Science, Cairo University.
}

\begin{abstract}
Purpose- Due to the competition in international markets, governments may intervene to raise the competitiveness of the exports through adopting certain measures, such as export promotion programs (commonly known as burdens refund programs). The purpose of this research paper is to test the effect of burdens refund export promotion program provided by the Egyptian government to the exporting companies of textiles, clothing and home textiles on their export performance through the period 2007-2019.

Design/methodology/approach- The panel data technique applied to test the effect of export promotion programs on export performance of textiles, clothing and home textiles. Effect of both global demand of textiles, clothing and home textiles and Egyptian pound exchange rate were tested as well. Data collected from export promotion fund, Central Bank of Egypt (CBE), and International Trade Center based on UN Comtrade.
\end{abstract}


Findings- The paper concluded that the burdens refund export promotion programs have a positive effect on the export performance of the textiles, clothing and home textiles in Egypt. Furthermore, it concluded that global demand has a positive impact and unexpectedly, depreciated exchange rate has a negative impact of the export performance of the three sectors.

Originality/ value- Due to the continued need to work on export performance, this paper develops and tests a holistic conceptual framework on export promotion programs submitted to textiles, clothing and home textiles exporters in Egypt and their effect on the export performance of these sectors. Furthermore, it provides background on some previous studies that may enable the policy-makers to learn from the best practices on how to design export promotion programs to raise competitiveness and promote exports of textile, clotting and home textiles in Egypt.

Key Words: Textiles, Strategic Trade Policy, Export Promotion Programs, Export Performance. 


\section{Introduction:}

The textiles, clothing and home textile industry has been among the most important industries in Egypt. It is the largest manufacturing sector for jobs creation, a key recipient of domestic and foreign investments, and a major source to foreign currency (Ghoneim, 2013). The industry represents thirty percent of manufactured value-added and provides thirty percent of industrial sector's employment in Egypt. Furthermore, it accounts for 15 percent of Egypt's non-oil exports, represents 3 percent of Gross Domestic Product (GDP) and, approximately total investments estimated at 6 billion US dollar (UNIDO, 2019; IMC, 2019).

Furthermore, Egypt's textiles and clothing industry has a vertically integrated production process and a value chain that includes the cotton growers, processors; exporters and retailers. Moreover, the industry has upstream and downstream linkages, which is a crucial factor for long-term competitiveness (UNECA, 2013).

Although the advantages the textile and clothing industry in Egypt have, however, international and domestic developments have negatively affected industry's position

and performance. Internationally, many developments in the multilateral rules governing the industry changed including the end of the Multi-Fiber Agreement (MFA), the gradual reduction of the quantitative restrictions, and entire abolishment of global quota ending in the mid-2000s. Domestically, there are many factors including weak of investments and lack of finance in the public sector, low productivity, and finally the cotton policy problems. These domestic factors prevented the development of the industry and deprived it from its comparative advantage. International and domestic developments constituted a strong pressure on the industry and made it imperative deal the new international rules and overcome the domestic challenges and to consider changing its orientation from the domestic market to export market (Ghoneim , 2013). 
Furthermore, the reduction of tariff levels around the world and the growing international competition imposed an intensified and increasingly competitive pressure on domestic industries that were subject to high protection, such as textiles and clothing industry. Therefore, it became imperative for the governments of developing countries to find out instruments to encourage exports under the new rules. Export promotion programs emerged to be one of such instruments (ITC; 2009).

Government encourages export because it contributes significantly in realizing countries' economic development; therefore, policy makers considers exports as a high priority when formulating strategic policies in their countries. Furthermore, governments, in both developing and developed countries, manage the foreign trade policy in a manner that affect domestic firm's business objectives to increase exports of their domestic firms (Shamsuddoha , 2004). Moreover, the successful experiences of some countries assure the importance of exports in economic development. For instance, the success of the outward-oriented economies of East Asia has been decisive in persuading the policy- makers of the importance of outward-oriented strategies and access to foreign markets for achieving their economic development (Bhagwati et al, 1987).

Furthermore, firms usually seek to expand internationally to achieve more revenues through strategic and financial perspectives. From strategic perspective, firms usually formulate certain strategic goals, inter alia, have a better market position in the

key international markets; achieve competitive advantage through market diversification; obtain modem technology available in the foreign market. Furthermore, firms aim to increase foreign market share; attain international experience; and building brand awareness in foreign markets. As for the financial perspective, firms set financial objectives to increase exports of products and achieving more profits through accession to international markets. Firms' success in 
increasing their exports and profits will improve their financial position (Shaoming et $a l, 2009)$.

Although the importance of the export promotion programs, however, there is critique that literature on export promotion lacks theoretical framework to explain how export promotion programs as a mechanism that enable firms increase their exports and test a few parameters relate export-promotion programs to export performance

(Leonidas et al, 2011). Export performance defined as the firms' activities in the international markets through the offer of goods and services. Generally, export performance is reflected in both growth and profitability of exports" ( Gitaniali and Kalesh, 2015)

In Egypt, the government provides burdens refund export promotion programs for textiles, clothing and home textiles industry to raise its competitiveness and enhance its export performance in international markets.

\section{The Purpose of the Paper:}

Due to the competition in international markets, governments may intervene to raise the competitiveness of the exports through adopting certain measures, such as export promotion programs. The purpose of this research paper is to test the effect of burdens refund export promotion program provided by the Egyptian government to the exporting companies of textiles, clothing and home textiles on their export performance through the period 2007-2019.

\section{The Importance of the Paper:}

Due to the continued need to work on export performance, this paper develops and tests a holistic conceptual framework on export promotion programs submitted to textiles, clothing and home textiles exporters in Egypt and their effect on the export performance of these sectors. Furthermore, it assures that, although the importance 
of burdens refund export promotion programs, however, they may not produce the aspired outcomes if not supported by global demand and flexible response to the devaluation of local currency.

\section{Research Methodology:}

This paper is an empirical analysis uses the panel data technique to test the effect of burdens refund export promotion program (as an independent variable) on the export performance of the textiles, clothing and home textile industry (as dependent variables). The econometric model used is:

$\operatorname{LnEXP}_{\text {it }}=\alpha+\beta_{1} \operatorname{LnBR}_{\text {it }}+\beta_{2} \operatorname{LnGD}_{\text {it }}+\beta_{3} \operatorname{LnER}_{\text {it }}+\varepsilon_{\text {it }}$ Where:

EXP is the explained variable, which is the export performance, and BR, GD and ER are the explanatory variables, which are the burdens refund, the global demand, and the exchange rate, respectively. $\mathrm{B}_{1}, \mathrm{~B}_{2}$ and $\mathrm{B}_{3}$ are the regression parameters to be estimated. $\alpha$ is the intercept, which is constant, and $\varepsilon$ is the error term in the model, $\mathrm{i}$ refers to industrial sector (i.e, textiles, clothes and home textiles), and t refers to the time.

Note: The exchange rate and global demand are included in the analysis to determine accurately what are the other factors may affect export performance of textiles, clothing and home textiles industry.

This paper organized as follows: (1) free trade versus strategic trade policy; (2) nature of export promotion programs; (3) literature review of export promotion programs; (4) export promotion programs in Egypt; (5) empirical analysis and results interpretation, and finally, conclusions and policy recommendations.

\section{Free Trade and Strategic Trade Policy:}


Free trade concept occupies a unique status among economists back in 1776 where since Adam Smith published his valuable book "An Inquiry into the Nature and Causes of the Wealth of Nations". Many economists have gave advocated the benefits of free trade in achieving economic development goals. Under free trade, national governments usually avoid controlling the exchange of goods and services across borders. Furthermore, they do not resort to imposing barriers to trade such as tariffs, and non-tariff barriers (Morales, 2010).

Classical economists Smith and Ricardo argued that eliminating the barriers to the free movement of goods would permit specialization and facilitate efficient utilization of domestic resources. They advocate free trade based on its role in enhancing competition in the domestic market; diversify consumer preferences; and supporting the spread of knowledge and technology, and thus enables developing countries to achieve their economic development (Gilpin, 2001).

Although traditional trade theory supports free trade; however, it allows potential justifications for deviating from free trade concept. Furthermore, not only large economies able to improve their terms of trade through imposing tariffs, but also small economies have a reason to impose tariffs on some industries if there was a domestic distortion that causes divergence between private and social costs (Krugman and Alasdair, 1994).

Because of the developments in international trade, free trade faced some doubts and became a debatable topic. Krugman (1987) argues that these new developments introduced a new stir of thought, which emphasizes that benefits of increasing returns and imperfect competition surpassed, to some extent, benefits from constant returns and perfect competition. Furthermore, Krugman, on one hand, views these developments as casting doubts at explaining trade by comparative advantage, and on the other hand, he assures that government's intervention, in some circumstances, may serve national economies' interests if a strategic trade policy such as import restriction or export incentive programs is adopted (Krugman, 1987). 
The roots of the new trade theory appeared in the beginning of 1980s, when both Brander and Spencer $(1983,1985)$ introduced a considerable analysis for trade policy within the framework of imperfect competition. In this regard, they introduced economies of scale, product specialization and technologies as other factors, which can work as a base for trade. Brander and Spencer's analysis pave the way for the introduction of activist strategic trade policy. This new trade theory provided the possibility that the government can enhance the competitive position of the national firms to access international markets and raise the national income at other countries firms' expense ( Orgun, 2012).

Although the new trade theory or the strategic trade policy introduced increasing returns and imperfect competition into the scope of international trade, however, it does not alter the crux of classical trade theory that trade is a win-win game. According to the doctrine of new trade theory, adopting a strategic trade policy may lead to enlarging markets and allowing better utilization of economies of scale, which means the gains from new trade theory surpass gains from the classical trade theory's comparative advantage concept (Krugman and Alasdair, 1994).

Strategic trade policy defined as "a trade policy that determines the outcome of strategic interactions between enterprises in current or potential international oligopoly" (Brander and Spencer, 2008). They assured that crux of the strategic trade policy is that national firms have to realize that their decisions of output and profits are not separated from the current or potential decisions of their competitors' decisions. In terse, the basic feature of the strategic trade policy is the strategic interaction between domestic and foreign rival firms (Brander and Spencer, 2008). Most importantly, the strategic trade policy through government's intervention can shift excess returns from foreign to domestic firms and favor industries that yield externalities (Krugman, 1987). 
Some economic views advocate the governments' role in affecting the profit shifting through adopting a strategic trade policy under oligopoly. For example, Eaton and Grossman (1983) argued that country's government could act as a Stackelberg leader in setting the proper trade policy before firms take decisions regarding prices or quantities. They believe that government policies such as taxes and subsidies can affect the competitiveness of domestic firms in international markets through improving their competitive position of cost and prices (Eaton and Grossman, 1983).

Bhagwati (1986) supports Eaton and Grossman's view where he confirms that government's commitment is essential for encouraging firms to take the decisions that may not be taken in the absence of government's commitment to assist such firms, to promote exports. Government's serious commitments to assist national firms allow them to undertake costly investments aiming to take advantage of export promotion strategy ( Bhagwati, 1986).

This section concludes two facts; first, there are mixed debate about the benefits of the free trade (Morales, 2010), second, government's intervention is essential to create a competitive position for domestic firms provided that such intervention takes into consideration accurate comparison of cost and gains. The successful government's intervention is subject to certain factors, enter alia, effective industrial policy, targeting industries that have dynamic competitive advantage, and finally coherence between education and training policies to meet the requirements of industrial sectors seeking to export and grow ( El Garf, 2002).

\section{Definition and Nature of Export Promotion Programs:}

There are many definitions of export promotion programs (EPPs). Belloc and Michele (2011) defined EPPs to be "the set of policies and practices which seek affect, directly or indirectly, export performance in a certain country”. OECD (1984) broadly defined EPPs as "the set of certain measures where government bearing a portion of 
cost of production of the private sector export. Ballassa (1976) defined EPPs as " a set of programs that aim to the increase of export profits through reducing costs or increasing revenues". Finally, Bhagwati (1990), narrowly defined EPPs as "the effective exchange rate policy".

The key purpose of export promotion programs is to achieve better export performance. These programs act as "external resource" to help domestic firms overcome numerous challenges to exporting. In this respect, governments use national export promotion programs to help domestic firms practice their export activities in a better efficient way and to minimize costs related to exporting ( Leonidas et al, 2011)

The crux of the export promotion programs is to enable domestic firms to obtain export competitive advantage comparing with rival foreign firms in export markets. The competitive advantage might be either a cost advantage, where the less unit cost leads to less selling price to customer in foreign markets, or a differentiation advantage, where the firm offers its customers high quality product compared with its competitors ( Ling-yee and Ogunmokun, 2001).

On the firm's level, exporting is a main pillar to achieve the sustainable competitive advantage in international markets. Increased exports enables firms to enhance technological standards, maximize capacity utilization, attain the desired performance and enhanced financial positions (Leonidou and Katsikeas, 1996). On the national level, exporting is an essential business activity that contributes in jobs creation, increases economic growth and raises the standard of living and increases the wealth of nations at the end of the day ( Czinkota and Ronkainen,1998).

\section{Literature Review on Export Promotion Programs:}


Export promotion programs have been widely applied by both developed and developing countries. Studying other countries' experiences in providing these programs and their effectiveness is critical to provide governments, intending to provide these programs, some guidelines to identify the best practices and learn from them (Belloc and Michele, 2011).

There is an increasing interest in the export literature concerning how the export promotion programs (EPPs) affect firms' export performance. The studies conducted in different countries have proved varied results about the relationship between EPPs and export performance (Wang et al, 2017).

This section discusses some of the previous studies examined the effect of export promotion programs on export performance. It categorizes export promotion programs according to countries provided them whether developing, developed, or developed and developing; export promotion agencies; and finally, the form of the program provided.

\section{(1) Studies conducted in developing countries:}

Fabrice et al, (2017) conducted a study on Nepal's Cash Incentive Scheme for Exports (CISE) that aimed to diversify markets where approximately 80 percent of Nepal's exports were going to only one-market, India. CISE ranged from 2 to 4 percent of the value of export transactions and introduced subject to two conditions: (i) domestic value-added not less than 30 percent, (ii) the product had to be exported to a country other than India. The study concluded that the specific requirements of domestic value-added and destination, has reduced the effectiveness of CISE in boosting exports.

Rodrik (1993) conducted analysis for export promotion program in both Bolivia and Kenya. Bolivia designed a program ranged from 5 to 10 percent for traditional and non-traditional exports, respectively. In Bolivia, the study reached 
those delays in payments and fraudulent practices led to the failure of the program. In a similar vein, Kenya applied export promotion program of 10 then 20 percent to most manufactured exports with a restriction that the value of imported inputs should not be more than 70 percent of the exports value. The study found that the eligible companies receive assistance after more than six months from the date of filling the required documents, and sometimes assistance were rejected without a reasonable justification, therefore, export promotion program did not achieve its goals in Kenya as well.

\section{(2) Studies conducted in developed countries:}

Francis and Colleen (2004) conducted a study to examine the relationship between export promotion programs and export performance of Small and Medium Enterprises (SMEs) in Canada. The study concluded that export promotion programs are important sources for enhancing the knowledge and expertise needed to access foreign markets and the use of these programs could influence export performance of firms. Furthermore, Gabriel and Erdal (2013) used sectoral data to measure the effect of export credit guarantees on the export performance in Germany. It concluded that one percent increase in credit export guarantees lead to increase in exports by percentage ranged from 0.012 to 0.017 percent.

\section{(3) Studies included both developed and developing countries:}

Mukherjee et al (2014) conducted a study over the period from 1990 to 2011 for 140 using an empirical panel data analysis to test impact of export promotion programs and merchandise exports in 140 countries at different levels of income. The study concluded that there is a positive relationship between export promotion program and export performance. The study concluded that there is a significant coefficient between export promotion program (as an independent variable) and export performance (as dependent variable) at significance levels of 1, 5 and 10 
percent respectively. Most impotently, the study reached that the greater the export support in higher income countries the greater the export orientation, on the contrary, in low income countries, the structural bottlenecks and lack of scale production disadvantage, negatively affected export performance.

(4) Studies relate to the export promotion agencies:

Lederman et al (2008) conducted a study relying on data from 88 developed and developing countries and concluded that export promotion agencies have a strong and statistically significant impact on the total volume of exports of the surveyed countries. It was found that for each additional US dollar allocated for export promotion, exports increase by about 40 US dollar.

Lederman et al, (2006), on a wider scope of countries, conducted a study covering 104 countries in Eastern Europe and Asia (EEA); Latin America and Carbian (LAC); Sub-Saharan Africa (SSA); Organization of Economic Cooperation and Development (OECD) and the Middle East and North Africa (MENA). The study aimed to test the effect of national export promotional agencies (EPA) on exports. The study concluded that, on average EPA has positive and statistically significant impact on export performance in these regions, furthermore, the study found that the efficiency of EPA increases monotonically with GDP per capita. In this respect, the impact of EPA on export performance was found larger in EEA; SSA; OECD, on the contrary, the impact of EPA on export performance in the MENA were lagging behind. Generally and on average, for all regions surveyed, for each $\$ 1$ of export promotion spent through EPA, it was found that approximately $\$ 40$ increase in exports.

\section{(5) Studies related to the type export promotion program provided:}

Xie (2014) conducted a study to examine the impact of export tax rebate and export volume in China, it concluded that, in long term 1 Ywan increase of export tax rebate lead to increase in the export volume by $\$ 0.90$, and $\$ 0.70$ in short term. The correlation coefficient between export tax rebate and export volume is highly 
significant and reached 0.99. Moreover, both Piyush and Cherly (2013) conducted a study to evaluate how VAT rebates affects Chinese exports. The study demonstrated significant and large effects of VAT rebates on export volume. For each \$1 of export tax rebates paid, there is an additional $\$ 4.70$ of export.

This section concludes that the literature proved that export promotion programs have positive effect on export performance, however, in some cases, programs are unsuccessful and this may be explained by the poor implementation of the national governments.

\section{Export Promotion Programs in Egypt:}

This section discusses the burdens refund export promotion program provided by the Egyptian government to textiles and clothing industry through 2007-2019, and the empirical analysis thereof. The Egyptian government provides export promotion programs to enhance the competitiveness of the domestic firms and enable them to access international markets.

The rational for providing export promotion programs to Egyptian exporters of varied manufacturing sectors is to give impetus to their exports. Export promotion programs were first designed to start with the manufacturing sectors in which Egypt has a comparative advantage and have demand in foreign markets and that other sectors will follow (Zied, 2007).

Export promotion fund established by virtue of the Law No.155 of 2002 to provide export promotion programs to the domestic firms in order to raise their competitiveness and increase exports. The export promotion fund provides the domestic firms the following activities: (1) assisting producers to increase their capacities through conducting technical and marketing research , (2) encouraging marketing national products in international markets, (3) reducing exporters' financial burdens to be in line with competitors in international markets (3) enhancing exporters' marketing and promotional capabilities in exporting goods and services. (4) 
Financing export-marketing studies and determine their qualitative and quantitative needs; and finally, (5) providing exporters with information on foreign markets' needs and specifications and conditions set on imported goods (Official Gazette, 2002)

The Egyptian government introduces three types of export promotion programs. First, basic export promotion programs: this type of programs is provided subject to certain criteria include; (1) the value added; (2) the location of the company; (3) export volumes, and (4) accession to new markets (Export Promotion Fund).

For the value added, the higher the value added the higher the burdens refunded. The Export Promotion Fund reimburses burdens according to the percentage of the domestic inputs used. Final exports manufactured from domestic inputs receive refund from $8 \%$ to $10 \%$ of the value of exports. Exports manufactured from imported inputs (Temporary Admission and Drawback) receive refund from 5\% to $8 \%$ of the value of exports. Exports from frees zones and manufactured domestic inputs receives refund from $5 \%$ to $7 \%$ of the value of exports manufactured. While the exports from free zone and manufactured from imported inputs receive refund from $3 \%$ to $4 \%$ of the value of exports manufactured (Export Promotion Fund) .

For the location of the firm, the firms located in remote areas receive more program assistance than those located in greater Cairo. Concerning export volumes, firms with exports less than US\$ 1 million dollar receives more assistance as a way of encouragement; as for accession to new markets, the promotion programs fixed for all firms (Export Promotion Fund).

Second, additional export promotion programs: this type of programs is provided subject to certain criteria include, (1) employment, where incentives increase proportionally with the increase of employment opportunities generated by the firm, (2) introducing innovated products, where firms receive additional incentive when new products introduced. Finally, (3) the complementarity between firms, 
where the interdependence between firms maximizes the domestic value added, therefore, they became eligible to receive additional incentives (Export Promotion Fund).

Third, other export promotion programs, which include, (i) fair enhancement program (ii) transport to Africa support program, and (iii) service environment enhancement program (Export Promotion Fund ( .

In Egypt, for export promotion programs to achieve their goals, these programs should have certain characteristics including (i) decrease start-up costs and time of companies capable of exporting, (ii) motivate and educate firms to adopt long term outlook in developing markets abroad where firms can recoup start- up costs, and ( iii) broaden the base for exporters. finally (v) organizational and human resources development challenges are to be addressed properly, otherwise, export promotion program may lead to a misuse of scarce public funds on misdirected activities providing minimal benefits to the business community (Nathan Associates Inc, 1998).

Egypt's export performance of the textiles, clothing and home textiles industry is subject to productivity, efficiency, and technology and production capacity; industry's ability to innovate; and diversify products. Furthermore, respond to changes in consumers' preferences and how to react to the changes in the international environment and to penetrate international markets (Sakr and Abdel Latif , 2000).

In the case of Egypt, the support of the Egyptian textiles, clothing and home textiles industry became a necessity to cope with the changes of the international trade environment and to increase its exports. This support takes the form of providing export promotion programs; enhancing the ways of accession to international 
markets; and raising the industry's competitiveness (Fawzy and Masowd, 2003). This view is supported by Sam (1997) who assured that export incentive programs may play a key role in enhancing exports through generating a supply response. He added that a whole gamut of industrial policies and trade reforms; improving export procedures; and securing competitive domestic market should exist in parallel to export promotion programs to enhance export performance.

Export promotion programs may not produce the aspired outcomes if not supported by economic policy adopting flexible exchange rate system. The Egyptian

government adopted a fixed exchange rate policy (before November 2016) regardless of its impact on the national economy and the competiveness of the Egyptian exports. Therefore, it became necessary that the government to liberalize the exchange rate along with providing export promotion program to offset the negative consequences on export because of exchange rate misalignment (Ministry of Economy and Foreign Trade, Egypt, 2001).

In the case of Egypt, there was a prolonged exchange rate misalignment; however, Egypt liberalized exchange rate mid November 2016, which is a necessary step to adjust the exchange rate misalignment. Liberalized exchange rate can enhance competitiveness; however, it is not sufficient to guarantee a notable improvement in the export performance. There other factors that affect the country's external competitiveness, other than exchange rate, enter alia, is affected by other factors, enter alia, the composition and the exportability of the domestic production ; the conducive environment where the exporting firms operate; and the effectiveness of trade policy of the country ( Youusef and Zaki, 2019).

Although both Zaki et al (2019) and Sam ( 1997) assure that the depreciated currency makes exports cheaper in foreign markets and increasing the demand 
thereof, and there is evidence of the strong correlation between the growth of exports and maintaining a stable, realistic effective exchange rate that can improve the competitiveness of exports. However, Noureldin (2017) concluded that prolonged exchange rate misalignment might have negative effect on export performance, particularly in cases where domestic currencies are overvalued. He concluded that most of empirical analysis indicates the negative effect of exchange rate misalignment on the general outward orientation of the economy, export performance and the overall economic growth of the country.

\section{Empirical Analysis:}

In this section, the authors analyze the relation between export volume and burdens refund in numerical terms, and then will apply the regression model. 


\section{|||||ICMBF}

3rd International Conference on Advanced Research in

MUNICH, GERMANY

MANAGEMENT, BUSINESS \& FINANCE

29-31 July, 2021

Table (1): Exports of Textiles, Clothing and Home Textiles, Burdens' Refund, Exchange Rate and Global Demand:

(values in 1000 US\$)

\begin{tabular}{|c|c|c|c|c|}
\hline Year & $\begin{array}{l}\text { TC and HT Exports } \\
\text { (1) }\end{array}$ & $\begin{array}{r}\text { Burdens' } \\
\text { Refund } \\
\text { (2) }\end{array}$ & $\begin{array}{r}\text { Exchange } \\
\text { Rate } \\
\text { (3) }\end{array}$ & $\begin{array}{r}\text { Global Demand } \\
\text { of textiles, clothing and home } \\
\text { textiles(4) }\end{array}$ \\
\hline 2007 & 652 & 140 & 5,6 & 502,118 \\
\hline 2008 & 1,764 & 174 & 5,4 & 561,278 \\
\hline 2009 & 2,475 & 156 & 5,8 & 481,428 \\
\hline 2010 & 2,905 & 144 & 6,2 & 587,755 \\
\hline 2011 & 3,436 & 159 & 6 & 658,629 \\
\hline 2012 & 2,915 & 163 & 6 & 640,903 \\
\hline 2013 & 3,105 & 106 & 7 & 688,382 \\
\hline 2014 & 3,020 & 97 & 7 & 704,780 \\
\hline 2015 & 2,958 & 117 & 7,7 & 641,772 \\
\hline 2016 & 2,519 & 64 & 10 & 619,919 \\
\hline
\end{tabular}




\section{|||||ICMBF}

3rd International Conference on Advanced Research in

MUNICH, GERMANY

MANAGEMENT, BUSINESS \& FINANCE

29-31 July, 2021

\begin{tabular}{|r|r|r|r|r|}
\hline 2017 & 2,822 & 13 & 17.9 & 659,622 \\
\hline 2018 & 3,186 & 25 & 17.9 & 691,101 \\
\hline 2019 & 3,260 & 27 & 17 & 556,911 \\
\hline
\end{tabular}

Sources: (1) and (2): Export Promotion Fund.

(3) Central Bank of Egypt (CBE).

(4) International Trade Center (ITC) Calculations based on UN Comtrade Statistics.

The figures in table (1) shows that the volume of textiles, clothing and home textiles exports doubled nearly four times in 2019 compared with 2007. This indicates that the export performance has an upward trend.

(the burdens refund reimbursed in Egyptian Pound (L.E), the figures in the above table are US dollar after conversion using the official exchange rate from Central Bank of Egypt (CBE)). 


\section{|||||ICMBF}

3rd International Conference on Advanced Research in MANAGEMENT, BUSINESS \& FINANCE
MUNICH, GERMANY

29-31 July, 2021

Figure (1): Textiles, Clothing and Home Textiles Exports and Burdens' Refund:

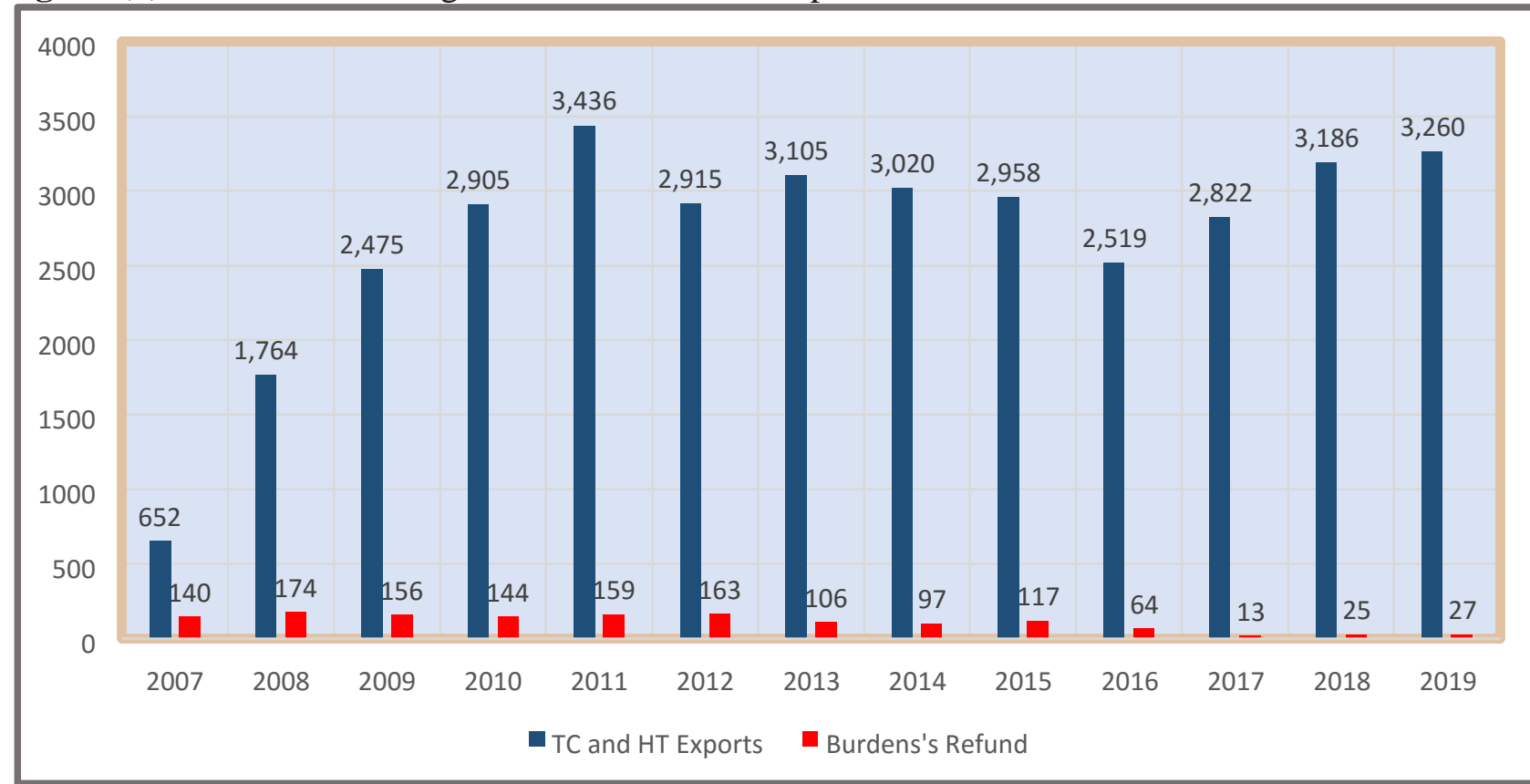

Source: Export Promotion Fund and Central Bank of Egypt ( CBE).

Figure(1) shows upward trend of exports, albeit fluctuation in some years.

Figure (2): Textiles, Clothing and Home Textiles Exports, Burdens' Refund and Exchange rate: 


\section{|||||ICMBF}

3rd International Conference on Advanced Research in MANAGEMENT, BUSINESS \& FINANCE

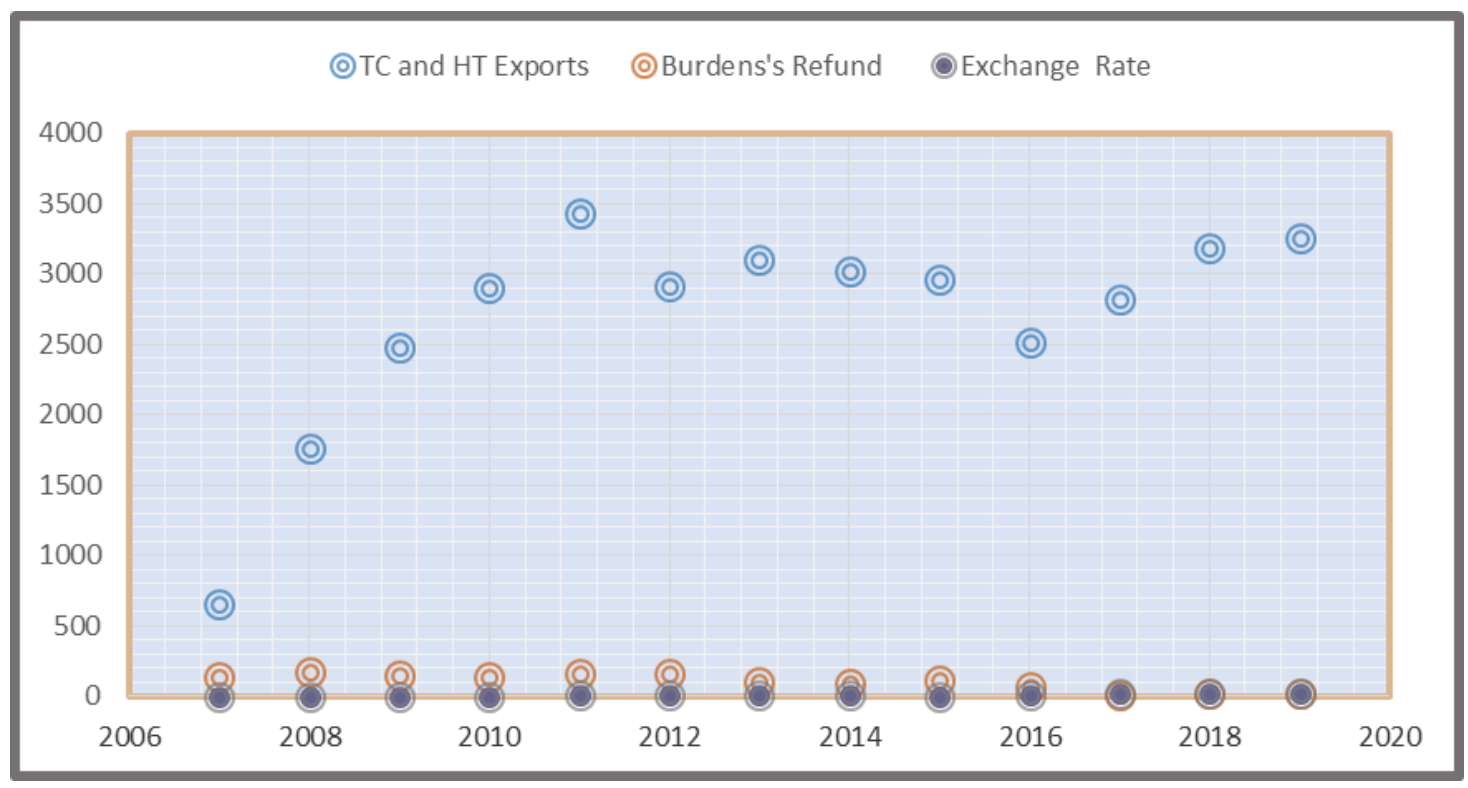

Source: Export Promotion Fund and Central Bank of Egypt (CBE).

Figures (2) presents the trend of exports of textiles, clothing and home textiles, burdens refund and exchange rate. While exports is upward trending, burden refund and

exchange rate tend to decline. It is noted that the value of burdens refund started to decrease in 2016, which is the year in which Egypt liberalized its exchange rate. Therefore, the value of burdens refunds in terms of dollar values sharply decreased.

Figure (3): Textiles, Clothing and Home Textiles Exports and Global Demand: 


\section{MANAGEMENT, BUSINESS \& FINANCE}

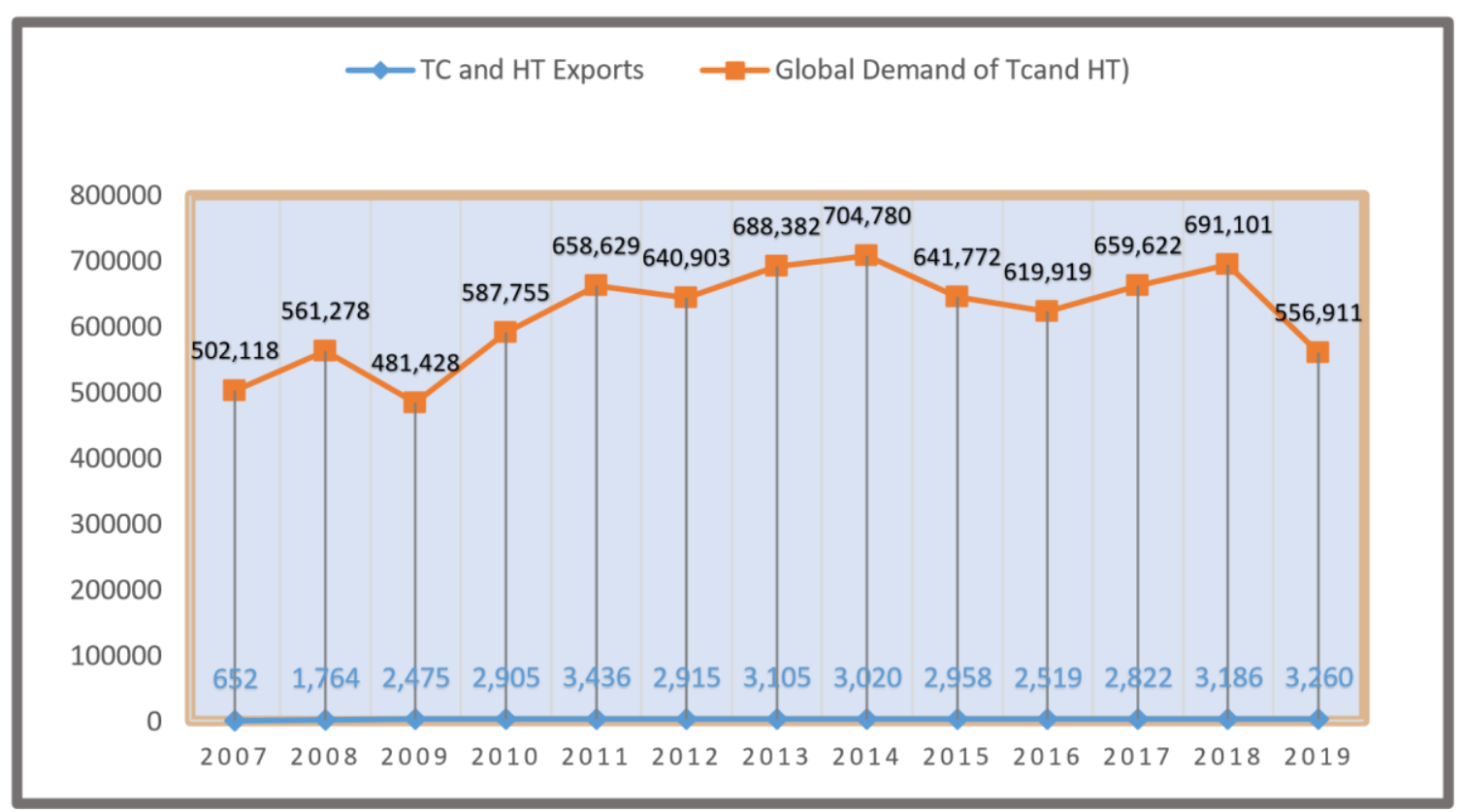

Source: ITC and Export Promotion Fund.

Note: TC means textiles and clothing, and HT means home textiles.

Figure (3) shows that there is a wide space for the textiles, clothing and home textiles export to move, particularly that the empuirical analysis showed that there a positive effect of glbal demand on exports of the three sectors.

\subsection{Regression Analysis:}

The authors applied a panel data technique to test the effect of burdens refund export promotion programs on export performance of the industry. They collected the monthly data of the exports of textiles, clothing and homes textiles and the burdens refund data from the Export Promotion Fund. They collected the data for the global demand of textiles, clothing and homes textiles form ITC Calculations based on UN Comtrade Statistics. As for the exchange rate and consumer price index (CPI), they collected the data from Central Bank of Egypt (CBE). 


\section{|||||ICMBF}

3rd International Conference on Advanced Research in MANAGEMENT, BUSINESS \& FINANCE
MUNICH, GERMANY

29-31 July, 2021

The authors ran four regressions using a panel data technique. They first introduced the refund alone (after deflating them by the CPI to obtain them in real terms). They have a positive effect on exports. Then, they added each variable alone (once with the exchange rate and once with the world demand). Finally, they added all the variables together.

Table (2) :Results of Empirical Analysis of the Data

\begin{tabular}{|l|c|c|c|c|}
\hline & $\operatorname{Ln}($ Exp.) & $\operatorname{Ln}($ Exp.) & $\operatorname{Ln}($ Exp.) & $\operatorname{Ln}($ Exp.) \\
\hline $\operatorname{Ln}($ Refund) & $0.0474^{* * *}$ & $0.0449^{* * *}$ & $0.0481^{* * *}$ & $0.0457^{* * *}$ \\
\hline & $(0.0148)$ & $(0.0144)$ & $(0.0149)$ & $(0.0144)$ \\
\hline $\operatorname{Ln}($ Demand) & & & & \\
\hline & & $(0.0316)$ & & $(0.0317)$ \\
\hline Ln(RER) & & & -0.381 & -0.512 \\
\hline & & & $(0.405)$ & $(0.395)$ \\
\hline Constant & $10.48^{* * *}$ & $7.883^{* * *}$ & $9.319 * * *$ & $6.274 * * *$ \\
\hline & $(0.158)$ & $(0.534)$ & $(1.250)$ & $(1.351)$ \\
\hline Observations & 458 & 458 & 458 & 458 \\
\hline R-squared & 0.2018 & 0.2469 & 0.2034 & 0.2498 \\
\hline Number of sector & 3 & 3 & 3 & 3 \\
\hline
\end{tabular}

Source: monthly data obtained from ITC, CBE and Export Promotion Fund.

Standard errors in parentheses

*** $p<0.01,{ }^{* *} p<0.05, * p<0.1$

The econometric model reached is as follows:

$\operatorname{LnEXP}_{i t}=\alpha+\beta_{1} \operatorname{LnBR}_{i t}+\beta_{2} \operatorname{LnGD}_{i t}+\beta_{3} \operatorname{LnER}_{i t}+\varepsilon_{i t}$ 


$$
\begin{aligned}
& \ln (\text { EXP. })=6.274+0.0457 \operatorname{Ln}(\text { Refund })+0.163 \operatorname{Ln}(\text { Demand })-0.512 \operatorname{Ln}(\text { RER }) \\
& \begin{array}{llll}
(1.351) & (0.0144) & (0.0317) & (0.395) \mathrm{p}<0.01
\end{array}
\end{aligned}
$$

\subsection{Interpretation of Results:}

The results can is interpreted as follows:

\section{Burdens Refund Export Promotion Program:}

The paper concluded that burdens refund export promotion program has a positive effect on the export performance of textiles, clothing and home textiles industry. The increase of the burdens refund by 10 percent will lead to the increase of exports of textiles, clothing and home textiles by 0.05 percent. The results appear to be substantiated by number of studies, enter alia, Lederman et al, 2006; Lederman et al, 2008; Gabriel and Erdal, 2013; Piyush and Cherly, 2013; and Xie , 2014.

The impact of burdens refund on export performance of textiles, clothing and home textiles is positive, however, it is not that significant and this can explained by the longer period of time the beneficiary companies consume to receive the burdens refund. In some cases, it can take more than 18 months for companies to receive the burdens refund, which makes the program effect, is limited in spite being positive. This interpretation is supported by Rodrick's (1993) conclusion that export promotion program was unsuccessful in Kenya due to that eligible companies for export promotion program receive had to wait for more than six months after claims has been filed.

\section{Global Demand on Textiles, Clothing and Home Textiles:}

The empirical results proved that global demand has a significant effect on export performance of textiles, clothing and home textiles industry. The increase in the global demand by 10 percent will lead to the increase of textiles, clothing and home textiles exports by 1.6 percent.

\section{The Exchange Rate Effect:}


Unexpectedly, the reduction of the change of exchange rate has a negative effect on the exports of textiles and clothing. The change in exchange rate by 1 percent will lead to decrease in export performance by 0.5 percent. Unfortunately, the conclusion of this study contradicts with the conclusion reached by other papers, for example, the real effective decrease in domestic currency value leads to increase in exports by 1.5 percent of the GDP. Moreover, another study concluded that decreasing domestic currency by 0.9 percent would increase exports by 1 percent of the GDP. Finally, the decrease of

domestic currency by 10 percent will increase exports by 1.8 percent (IMF, 2015; Genc, and Kibritci, 2014; Berman et al, 2012).

Zaki et al (2107) provided an accurate explanation for: why the exports of textiles, clothing, and home textiles did not respond positively to the changes in the changes in the exchange rate. Zaki et al found that traditional export group of textiles such as cotton, articles of apparel and man-made staple fibers, are sensitive to exchange rate depreciation. (Zaki et al, 2017).

\section{R-Squared:}

$\mathrm{R}^{2}$ is 0.25 , which is rather low in explaining the relationship between export performance (the dependent variable) and the burdens refund (independent variable). 


\section{Conclusions and Policy Recommendations:}

Export promotion is crucial on both firms and national levels, particularly for developing countries such as Egypt. On the firms' level, exporting enables firms to expand in international markets, improve technological standards, maximize production capacity, and achieve better financial positions. On the national level, exporting contributes in jobs creation, increases economic growth and raises the standard of living of population.

Prompting the exports of textiles, clothing and home Textiles in Egypt plays an important role in economic development, provided that their competitiveness raised and their export performance enhanced. To achieve this goal the Egyptian government provides export promotion programs in the form burdens refund through the Export Promotion Fund subject to certain criteria discussed in this research paper.

Using monthly sector-level data, this paper tried to test the effect of burdens refund export promotion programs on export performance of textiles, clothing and home textiles in Egypt through the period 2007 -2019. The paper concluded that the burdens refund export promotion programs had a positive effect on the export performance of the textiles, clothing and home textiles. However, this positive effect is insignificant, where increasing of the burdens refund by 10 percent lead to the increase of exports by 0.05 percent. This insignificant effect can be explained by the longer period of time the exporters consume to receive the due burdens refund from the Export Promotion Fund.

Based on a face-to-face inquiry with the officials of the export promotion council of textiles, clothing and home textiles on the main challenge they face. They focused on the delay of the reimbursement of burden refund to the exports where this process consume more than 18 months, which may have an indirect effect in the weak effect of export promotion programs on the export performance of these sectors. Mukherjee et al (2014) supported this conclusion where the absence of statistically significant effect of export promotion programs on export performance by the poor 
implementation of these programs by the national governments. Furthermore, it supported by Rodrik (1993) who concluded that export promotion program was unsuccessful in Kenya due to that eligible companies for receiving export promotion program had to wait for more than six months after their claims for export promotion allocations.

Unexpectedly, the paper concluded that depreciated exchange rate had negative effect of the export performance of the three sectors. The reason for this unexpected outcome is that only traditional export group of textiles such as cotton, articles of apparel and man-made staple fibers, are sensitive to exchange rate depreciation. Regarding the conclusions on exchange rate and export performance, this paper contradicts with the conclusion reached by other papers (IMF, 2015; Genc, and Kibritci, 2014; Berman et al, 2012), that proved positive relationship between currency devaluation and export performance.

Furthermore, it concluded that global demand had a positive effect on the export performance of textiles, clothing and home textiles in Egypt, which means that the textiles, clothing and home textiles are capable to respond to the global demand. .

The conclusions reached are substantiated by number of studies discussed in this paper, enter alia, Lederman et al, 2006; Lederman et al, 2008; Gabriel and Erdal, 2013; Piyush and Cherly, 2013; and Xie , 2014.

This paper presents the following recommendations to enhance export performance of Egypt's textiles, clothing and home textiles:

(1) Accelerating the reimbursement of burdens refund to the beneficiary companies once the export transaction is complete and the required documents submitted and verified by the Export Promotion Fund's official, (2) enhancing the competitiveness of all items textiles, clothing and home textiles to be capable to benefit from the flexibility of the new exchange rate devaluation,. (3) Increasing 
investments in public sector companies involved in the production of textiles, clothing and home textiles, and (4) adopting an agricultural policy that produces cotton in quantities and specifications needed by the Egyptian mills.

Finally, diversifying Egypt's export destinations and maximizing the benefit from the trade agreements such as Common Market for Eastern and Southern Africa (COMESA), Qualified Industrial Zones (QIZ), Greater Arab Free Trade Area (GAFTA), Egyptian -European Partnership, and African Continental Free Trade Area (AfCFTA).

\section{References:}

- Ballassa, Bela.1980. The Process of Development and Alternative Development Strategies, Essays in International Finance No.141,Princeton University, Princeton, New Jersey, p.15.

- Ballassa, Bela.1976. Export Incentive and Export Performance in Developing Countries: A Comparative Analysis,pp.46-48

- Belloc, Marianna and Michele Di Maio.2011. Survey on the Literature of Successful Strategies and Practices for Export Promotion by Developing Countries, Working Paper, International Gowth Center (IGC), June 2011.

- Berman, Nicolas et al .2012. How do Different Exporters React to Exchange Rate Changes? The Quarterly Journal of Economics, Volume 127, Issue 1, February 2012, Pages 437-492,

- Bhagwati, Jagdish N. 1990. 'Export-promoting Trade Strategy: Issues and Evidence', in Export Promoting Strategies, Theory and Evidence from Developing Countries edited by Chris Milner New York: New York University Press), pp 1139. 
MUNICH, GERMANY

29-31 July, 2021

- Bhagwati, Jagdish N et al .1987. The World Bank Economic Review, Introduction, Vol.1, No.4.Symposium (Sep.1987) pp. 539-547, Oxford Journals, Oxford University Press, p.539.

- Bhagwati, Jagdish N.1986. Export Promoting Trade Strategy: Issues and evidence, the World Bank, Development Policy Issues Series, Discussion Paper, October, 1986,pp-14-15.

- Brander A.James and Spencer J. Barbara.1984. Export Subsidies and International Market Share Rivalry, Working Paper No.1464, National Bureau of Economic Research (NBER), Cambridge, September 1984.

- Chandra, Piyush and Cherly Xiaoning Long.2013. VAT rebates and export performance in China: Firm-level evidence, Journal of Public Economics 102:1322, June 2013.

- Czinkota M.R.and I.A. Ronkainen. 1998. International Marketing. - Fort Worth, TX: Dryden Press, in Ural, Tulin and Songul Khalilli Acaravci. 2018. "The Effects of Firm's Strategic Factors on Export and Firm Performance: A Comparison of Permanent and Sporadic Exporters", Business Perspectives, p.43.

Defever, Fabrice et al. 2017. All These Worlds Are Yours, Except India: The Effectiveness of Export Subsidies in Nepal, Policy Research Working Paper, WPS8009, Trade and Competitiveness Global Practice Group, World Bank Group, March 2017.

- Eaton, Jonathan and Gene M. Grossman. 1983. Optimal Trade and Industrial Policy under Oligopoly, NBER Working Paper Series, Working Paper No.1236, November 1983.p.1.

- El Garf, Mona.2002. The Concept and Determinants of Competitive Advantage: A Reference Survey, Economic Studies, Center for Economic \&Financial Research \&Studies,( CEFRS),Faculty of Economics and Political Science, Cairo University, Vol.(14), pp.44-45. (Arabic) 
- El Garf, Mona.2005. Institutional Alternatives for Restoring Balance between the government and Markets' Roles in Egypt, Egyptian Center for Economic Studies(ECES), Working Paper No.(104), p.21.( Arabic).

- Export Promotion Fund, Export Promotion Programs, Internal papers.

- Faroque R.A and Takahashi .Y. 2012. Export Assistance: The Way Back and Forward, Springer Briefs in Business, p.1.

- Fawzy, Sameha and Nada Masowd. 2003. The Future of the Egyptian Textiles and Clothing Exports within the Framework of the New Rules of International Trade, Working Paper No.86, the Egyptian Center for Economic Studies (ECES), June 2003.

- Felbermayr J. Gabriel and Erdal Yalcin . 2011. Export Credit Guarantees and Export Performance: An Empirical Analysis for Germany, ifo Working Papers, WP No.116, 03 May 2013

- Francis, N. June and Collleen Marie Cllins. 2004. Impact of Export Promotion Programs on Firm Competencies, Strategies and Performance: The Case of Canadian High-Technology SMEs, International Market Review, Vol.21, No.4/5.

- Genc, Elif Guneren and Oksan Kibritci.2014. The Effect of Exchange Rate on Exports and Imports of Emerging Markets, European Scientific Jounal, Vol.10, No.13: 128-141, p.137.

- Ghoneim, Farouk Ahmed.2013. Ready Made Garments ( RMG) Industry: Is There a Way to Save It? Policy Brief 011, Egypt Network for Integrated Development, Egypt Network for Integrated Development, 2013.

Gilpin, Robert. 2001. Global Political Economy: Understanding the International Economic Order, Chapter 8, the Trading System, Princeton University Press, 198.

- IMF.2015.Exchange Rate and Trade Flows: Disconnected? In World Economic Outlook: Adjusting to Lower Commodity Prices. p.105.

- Industrial Modernization Center (IMC).2019. Textiles' Sector Background PowerPoint Presentation. 
- International Trade Center, Export Promotion and the WTO: A brief Guide, Introduction, 2009, pp.4-6.

- International Trade Center, Calculations based on UNC OMTRADE Statistics, https://www.trademap.org/countrymap/Country_SelProductCountry,TS.aspx?nvpm

- Jindal, Gitanjali and Kamlesh Gakhar.2015. Export Promotion Programs and Exporters' Performance, Strategies and Competencies: A Review, p.172, International Journal of Research in Management, Science and Technology, Vol.3, No.4, December 2015.

- Jung S. Woo and Gyu Lee.1986. The Effectiveness of Export Promotion Policies: The Case of Korea, p.350.

- Krugman, R.Paul. 1994. Introduction to "Empirical Studies of Strategic Trade Policy, edited by Krugman, Paul and Alasdair Smith, Empirical Studies of Strategic Trade Policy, University of Chicago Press, USA, p.1.

- Krugman, R.Paul.1987. Is Free Trade Passe?, The Journal of Economic Perspectives, Vol.1. No.2.pp 131-144, published by American Economic Association, JSTOR.p.134.

- Laird, Sam.1997. WTO Rules and Good Practices on Export Policy, Staff Working Paper 9701, Trade Policy Review Division, World Trade Organization, March 1997.

- Lederman, Daniel et al .2008.Export Promotion Agencies: What Works and What Doesn't, CEPR Discussion Paper. Development Research Group, World Bank.

- Lederman, Daniel et al .2006.Export Promotion Agencies: What Works and What Doesn't, The World Bank, p.3 and p.24.

- Leonidou C. Leonidas et al .2011. National Export-Promotion Programs as Drivers of Organizational Resources and Capabilities: Effects on Strategy, Competitive Advantage, and Performance, Journal of International Marketing, Vol.19, No.2, June, 2011.

Leonidou C, L, and C.S. Katsikeas. 1996. The Export Development Process: an 
Integrative Review of Empirical Models, Ural et al “ the Effects of Firm's Strategic Factors on Export and Firm Performance: A Comparison of Permanent and Sporadic Exporters, Business Perspectives, Journal of International Business Studies.

- Linag, Xie.2014. Effect of Export Tax Rebate on Export Volume: Evidence from China, pp.33-34.

- Li, Ling-yee, and Gabriel Ogunmokun. 2001. Effect of Export Financing Resources and Supply-Chain Skills on Export Competitive Advantages: Implications for Superior Export Performance, Journal of World Business, Volume36, Issue 3, pages 260-279, ELSEVIER.

- Ministry of Economy and Foreign Trade.2001. Egyptian Exports Promotion Strategy, the first year, Egypt, p.16 (Arabic).

- Morales, Meoqui Jorge. 2010. Classical Trade Theory: A Policy towards Economic Growth and Development, Doctoral Thesis, WU Vinna University, p.2.

- Mukherjee, Sacchidananda, et al. 2014. Influence of Subsidies on Exports Empirical Estimates, Policy Evidence and Regulatory Prospects, Working Paper Series, WPEC- No.14-22, Indian Institute of Foreign Trade, March 2104.

- Nathan Associates Inc.1998. Enhancing Egypt's Export Promotion Programs: Micro Strategies, p.3.

- Noureldin , Diaa. 2017. Much Ado About the Egyptian Pound: Exchange Rate Misalignment and The Path Towards Equilibrium, Working Paper No.190, the Egyptian Center for Economic Studies(ECES), Cairo, Egypt, December 2017.

- OECD.1984. Competition and Trade Policies: Their Interaction, OECD Publishing, Paris.

- Orgun, Orham Bilgin.2012. Strategic Trade Policy Versus Free Trade, ELSEVIER, 8th International Strategic Management Conference, Procedia, Social and Behavioral Sciences 58(2012), 1283-1292, p.1284. 
- Rodrik, Dani. 1993. Taking Trade Policy Seriously: Export Subsidization as a Case Study in Policy Effectiveness, WP no. 4567, NBER Working Paper Series, pp.2224.

- Sakr , F.Mohamed and Lobna M. Abdel-Latif.2000. International Competitiveness of Egypt's Textile Industry, Economic Studies, Vol (14), Center for Economic \&Financial Research \&Studies (CEFRS), Faculty of Economics and Political Science, Cairo University, May 2000.

- Shamsuddoha K., A.2004.Antecedents of Firms Export Performance: The Role of Export Promotion Programs, Chapter 1, Introduction, A thesis submitted in fulfillment of the requirements for the degree of Doctor of Philosophy, Faculty of Business Queensland, University of Australia, p.1.

- Spencer, J. Barbara and James A. Brander. 2008. Strategic Trade Policy, Edited by Durlauf N. Steven and Lawrence E. Blume "The New Palgrave Dictionary of Economics" Second Edition, Palgrave Macmillan, London, p.1.

- The Egyptian Official Gazette .2002. Law No.155/2002 Concerning Export Promotion, Issue No.24 ( Supplementary), June 18, 2002 (Arabic).

- United Nations Economic Commission for Africa.2013. Economic Report on Africa, African Union, Country Case Study, Egypt.

- United Nations Industrial Development Organization (UNIDO).2019. ABSTRACT OF 160068 Project, Document, and Accessed on July 16, 2019 available at https://www.ungm.org.

- Wang, Xinxin.2013. The Determinants of textiles and apparel export performance in Asian countries, Iowa State University, $\mathrm{p}$.

- Wang, Xiaoting et al. 2017. Effect of Export Promotion Programs on Export Performance: Evidence from Manufacturing SMEs, Journal of Business Economics and Management, Vol.18 (1):131-145, p.131.

- Youssef, Hoda and Chahir Zaki. 2019. From Currency Depreciation to Trade Reform: How to Take Egyptian Exports to New Levels? Policy Research Working 
Paper 8809, Macroeconomic, Trade and Investment Global Practice the World Bank Group, April 2019.

- Zaki, Chahir et al. 2019. How Do Trade Margins Respond to Exchange Rate? The Case of Egypt, Working Paper No.189, the Egyptian Center for Economic Studies (ECES), Cairo, Egypt, November 2017.

- Zied, Shaimaa.2007. The Impact of Exchange Rate Policy Textiles and ReadyMade Garments Foreign Trade in Egypt, PhD Thesis, Economic Section, Faculty of Commerce, Ain Shams University, Egypt, p.134 (Arabic).

- Zou, Shaoming et al.2009. Introduction, Export Market Strategy, Chapter1, Zou et al, Export Marketing Strategy Export Marketing Strategy: Tactics and Skills that Work, Business Expert Press, New York, NY, p.3.

- Zou, Shaoming and Simon Stan.1998. The Determinants of Export Performance: A Review of the Empirical Literature between 1987 and 1997, International Market Review Vol.15, No.5, MCB University Press, June 1998. 